\title{
Knowledge, Skills and Competences of a High School Foreign Language Teacher of Today
}

\author{
MA. Vjollca (Tabaku) Hoxha \\ Department of English Language, Faculty of Foreign Languages \\ University of Tirana, Albania \\ Email: vjollcatabaku@hotmail.com
}

\section{Doi:10.5901/jesr.2013.v3n7p118}

\begin{abstract}
The way we live, work, play and learn has been greatly transformed by technology and the new inventions over the past years. Today we need more different skills than we did in the 20th century, and the educational system and institutions have a crucial role to play in developing those skills. The knowledge and performance required of teachers today, should meet the demands of the classroom of the 21st century. The 21st century will need people who have 21 st century skills like problem-solving and critical thinking, creativity, analyzing, creating and offering solutions to problems, capable to live and work at home and abroad. What does it mean to be a highly effective foreign language teacher today? What are the competencies that high school foreign language teachers must possess and demonstrate to enable their students to attain high learning outcomes and be prepared for life? In this article we will try to give answers to these questions by outlining a model of knowledge, skills, and competences of a high school foreign language teacher of today.
\end{abstract}

Keywords: 21st century, high school teacher, skills, competences, knowledge

\section{Introduction}

Societies challenge one another with the quality of their intellectual capital today and in order to be part of today's globalized, knowledge-based economy successfully, countries of the world need to have innovative, creative and entrepreneurial citizens.

This shift in the global age and its needs call for an adaptive reaction from us; we need to compete, collaborate, and find solution to problems through competencies in languages and cultures other than our own.

"Education is at the heart of human progress. Economic and social prosperity in the $21^{\text {st }}$ century depend on the ability of nations to educate all the members of their societies to be prepared to thrive in a rapidly changing world. An innovative society prepares its people to embrace change..." [G8 Summit Statement 2006, St. Petersburg]

Indeed, the way we live, work, play and learn has been greatly transformed by technology and the new inventions over the past years. Today we need more different skills than we did in the $20^{\text {th }}$ century, and the educational system and institutions have a crucial role to play in developing those skills.

"Teaching will be a better job when we recognize that the world has changed, and the job of a teacher is to help young people learn ask good questions, not regurgitate answers. With the flood of information around them, young people need help separating wheat from chaff. And it's no longer the teacher's job to tell them the difference, but to give them the skill to inquire, to dig deeper." ${ }^{1}$

The knowledge and performance required of teachers today, should meet the demands of the classroom of the 21 st century. The $21^{\text {st }}$ century will need people who have $21^{\text {st }}$ century skills like problem-solving and critical thinking, creativity, analyzing, creating and offering solutions to problems, capable to live and work at home and abroad.

What does it mean to be a highly effective foreign language teacher today? What are the competencies that high school foreign language teachers must possess and demonstrate to enable their students to attain high learning outcomes and be prepared for life?

\footnotetext{
${ }^{1}$ Merrow, J. (2011) The Influence of Teachers: Reflections on Teaching and Leadership: New York, LM Books.
} 


\section{The classroom of the 21 st century}

The language classroom has changed a lot in the last 20 years being transformed so as to reflect the increasing emphasis on developing students' communicative competence. Students now are not required to know a great deal of information about the language and not be able to use it; today's classroom is about teaching languages in a way that students gain the ability to communicate freely with the speakers of the language, to find it easy to use the language when abroad for living, working or tourism.

Before students learned about the language and mostly grammar, today they learn how to use the language. If before the class was teacher-centered, today it's learner-centered. This causes another change; from emphasis on the teacher as a presenter there's focus on the learner as a doer. Language learning was confined to the classroom, now students are told and provided opportunities to use the language outside the classroom, as well. Focus was put on isolated skills such as listening, reading, speaking, and writing, but today teaching prepares student to be able to interpret and present and have interpersonal communication. Evaluation and testing was to learn what students did not know, now assessing aims at finding out what students can do. If before students had their work prepared just to be marked by the teacher, now they learn to share and publish their work.

\section{Foreign language teacher competencies}

Foreign language teachers must obtain and demonstrate adequate linguistic proficiency in the language they will teach together with an understanding of the structure of the language. Since language and culture are closely linked, foreign languages teachers' competence in the language should also include in-depth cultural knowledge and understanding of the language. Knowledge of second language acquisition and learner development, as well as pedagogical skills appropriate to the setting they will be teaching are to some more competencies to be added to the list.

\subsection{Foreign language teacher's language proficiency and content knowledge}

Most of the teachers in the world are not native speakers of the language they teach and yet, they might be successful teachers. And seemingly not all native speakers are good teachers. So how much of the language they teach should the teachers know in order to be able to teach it effectively?

The language-specific competencies that a foreign language teacher needs to have include the following abilities:

- to give explanations and instructions in the target language; maintain use of target language in the classroom

- to use appropriate classroom language

- to provide good language models

- to comprehend texts accurately

- to select target-language resources

- to monitor his/her own speech and writing for accuracy

- to provide input at an appropriate level of difficulty

- to provide examples of words and grammatical structures and gice accurate explanations

- to give correct feedback on learner language

As about the content knowledge a teacher should know, there is little agreement concerning what the academic subject matter of language teaching matter is. Content knowledge refers to what teachers need to know about what they teach (including what they know about language teaching itself), and constitutes knowledge that would not be shared by teachers of other subject areas. ${ }^{3}$

"When language teaching emerged as an academic discipline in the 1960s, this disciplinary knowledge was largely drawn from the field of linguistics, but today it encompasses a much broader range content. For example, it could include the history of language teaching methods, second language acquisition, sociolinguistics, phonology and syntax, discourse analysis, theories of language, critical applied linguistics, and so on."4

\footnotetext{
2 Richards, C., J., (2011) Competence and Performance in Language Teaching, CUP.

${ }^{3}$ Richards, C., J., (2011) Competence and Performance in Language Teaching, CUP.

4 Richards, C., J., (2011) Competence and Performance in Language Teaching, CUP.
} 


\subsection{Teaching skills}

Teachers need to acquire some basic teaching skills needed in the process of teaching, to present and maintain a lesson. A repertoire of techniques and routines are needed to open the lesson, organize work in the classroom, introduce and explain tasks, manage passing from one task to another, and monitor students' work and language use. Over time and with the gaining of experience, these skills are performed fluently and automatically making it possible for teachers to focus their attention on other features of the lesson.

\subsection{Knowledge on the language's culture}

All teachers should know the intellectual and artistic achievements of the culture of the country and people whose language they are teaching, basic concepts and developments of the political and history of that culture, the most important facts and concepts related to the economic and political geography of the culture as well as formal and informal culture practices. Teachers should use authentic cultural sources and they should take into account students' cultural backgrounds.

\subsection{Application of appropriate pedagogical principles}

Teachers should be informed on the ever-evolving knowledge of language acquisition because they plan, select and develop the language-teaching activities based on that knowledge and current development. This involves knowledge on different learning styles and ability to recognize each one and help students to develop their own learning styles; knowledge on what makes a language-learning environment successful and how to choose, structure and develop cooperative learning activities; knowledge on strategies for increasing in students a positive attitude and motivating them towards the learning of a language.

Apart from the above mentioned skills and knowledge, which have always have been a part of a teacher's preparation (but now need to be in line with the new discoveries and advances) we need to mention a few more which are required from a teacher to have in order to be a $21^{\text {st }}$ century teacher preparing $21^{\text {st }}$ century citizens:

\section{Use of ICT}

Today digital technology is changing every aspect of people's lives. Information and communication technology (ICT) in a short time has become very important in our society. In many countries it is regarded as an essential part of education and mastering the basic concept and skills of ICT is considered to be as important as knowing how to read and write.

A new aspect of learning in the 21 century is the Lifelong Learning. Research has shown that if used properly ICTsupported education can help learners acquire the knowledge and skills that will make possible the lifelong learning. "A comprehensive and coherent lifelong learning strategy for Europe should aim to provide lifelong learning opportunities as close to learners as possible, in their own communities and supported through ICT-based facilities wherever appropriate." (European Commission's Memorandum on Lifelong Learning, 2000).

We tend to raise the number of digital illiterate people which in turn can be achieved by equipping schools, teachers and students with the necessary material, professional skills and technical support. The effective use of ICT will very much contribute to the implementation of lifelong learning by widening access and introducing more varied ways to learn.

Teachers are a key component in the process of learning but teachers have to understand that their roles have changed. They have to remember that "electronic communication can help foster a new teacher-student relationship in which the students become more autonomous and the teacher becomes more a facilitator." (Warschauer M. 1995). The use of ICT allows for the lesson to be more learner-centered. The classroom environment is more cooperative and collaborative and more active learning takes place.

Their workload in the classroom might be reduced in the $21^{\text {st }}$ century but they need to work more on planning the steps in a class as well as developing their skills and knowledge of ICT. When the newly qualified teachers step out of the comfort zone of the college to the cacophony of the classroom, many are expected to work with ICT products and services they have never previously experienced. For some adapting to untried tools is fairly easy, but for others, confidence can be knocked by anxiety about adoption of unfamiliar classroom technologies. 


\section{Engaging in action research}

Action research is an expanding field which is commanding significant education attention. It is a methodology of paramount importance in teacher education programs as it offers an approach to introducing innovations in teaching and learning. Kemmis and Mc Taggart argue that "to do action research is to plan, act, observe and reflect more carefully, more systematically, and more rigorously than one usually does in everyday life. ${ }^{.5}$ Action research is a way to grow and learn by making use of one's own experiences.

The report on European Profile for Language Teacher Education-A Frame of Reference, proposes that the foreign language teacher education in the $21^{\text {st }}$ century should include certain elements of initial and in-service education among which, continuous improvement of teaching skills as part of in-service education (element 10) and ongoing education for teacher educators (element 11). As part of their in-service or continued education teachers should develop skills in action research, reflective practice, creative use of materials, resources and new learning environments and mentoring. "Qualified teachers benefit from keeping a "learning diary" to reflect on their experience and identify areas that might benefit from action research projects. Learning further skills in action research would be a key part of continued education, since it is easier to solve a problem if it is one's own." ${ }^{6}$ Action research also encourages teachers to find new ways of doing things.

\section{Project work}

Project work is not a new teaching method. Its benefits have been widely recognized in teaching many different subjects, language teaching as well. It is a highly adaptable teaching methodology and can be used at every level, from beginner to advanced, and with all ages. Project work is important because it is among those activities which foster students' autonomy.

"Project-based learning is a model for classroom activity that shifts away from the classroom practices of short, isolated, teacher-centered lessons and instead emphasizes learning activities that are long-term, interdisciplinary, student-centered, and integrated with real world issues and practices." [Asan \& Haliloglu, 2005].

$\mathrm{PBL}$ is a powerful tool in the hands of a teacher. It requires a great deal of investment on the part of the teachers to become effective facilitators. Designing and implementing a good project requires efforts on the teacher's part; they need to make sure of using project work at the right time and for the right reasons. It also requires efforts from the students, who may be used to being told exactly what to do.

Educators' role in project work should be less dominant. They are facilitators and not the only source of knowledge or provider of all solutions. Teachers assist project work as fellow learners, coordinators. At all stages of project work the teacher should suggest ideas, provide references, provide alternatives to a situation or stimulate students to think. Great importance should be given to the fist phase, that of the preparation for the project. Preparation, then, is the key to make project work a success. [Hutchinson, 2001]. Taking the role of a guide or facilitator is not the way that most educators were taught, nor even the way they were taught to teach. Thus, a suggestion to improve project work in Albania would be to improve teachers knowledge and skills in project conducting by giving them all the administrative support needed as well as providing some kind of training. Professional collaboration among teachers is another way of improvement. Being able to share with colleagues, project ideas, strategies, resources, and results can make a great difference for educators, especially during the early stages of their career or PBL efforts.

\section{Alternative assessment and Self-evaluation}

"As part of a broader assessment reform movement, conceptions of good assessment are moving toward direct observation of complex performance rather than brief written tests that correlate with the target aptitudes." 7

"Teachers are today experimenting with alternatives to traditional tests. Performance assessment, portfolio collections, classroom observation, peer assessment, and self-evaluation are joining the unit test and the final exam in

\footnotetext{
${ }^{5}$ Kemmis, S. and Mc Taggart, R. The Action Research Planner (third edition) Geelong, Victoria, Australia: Deakin University Press, 1992, pág 10

${ }^{6}$ Kelly, M., Grenfell, M., Allan, R., Kriza, C., Mcevoy, W. European Profile for Language Teacher Education-A Frame of Reference: September 2004 pág 39.

7 Linn, R., Baker, E., \& Dunbar, S. (1991) Complex performance-based assessment: Expectations and validation criteria, Educational Research, 20 (8), 15-21.
} 
the repertoire of the skillful teacher. ... While teacher-made tests and standardized tests give us information about student learning, they do not provide all the information. Alternate forms of assessment can generate that other information. ... The research evidence accumulating in our studies, and other data produced by other researchers, make us optimistic about the impact of one form of authentic assessment - self-evaluation - on the learning of students and their teachers. "8

A new aspect of learning in the 21 century is the Lifelong Learning. Member states of the European Union are asked to prepare strategies, take action and organize systems in order to encourage and sustain lifelong learning for all. In order to become lifelong learners, students need to know the importance of self-evaluation. Being able to evaluate oneself fairly and helpfully is a valuable life skill which will be an asset to people long after they leave collage. When evaluating themselves, students better understand their weaknesses and strengths.

\section{Professional growth}

The secret of success in the profession of teaching is to continually learn and grow professionally. Professional development is defined as a continuous learning process in which teachers undertake voluntarily to learn how to match their teaching to the learning needs of their students. Professional development is not a single isolated event, but rather an ongoing process of professional reflection and growth which develops gradually and gives the best results when sustained over time and when focused on knowledge and skills matching the changing demands of jobs and occupations, workplace organization and working methods.

Teachers aim at equipping learners with a wide range of skills that they will need to live, study and work in a world that is in constant evolution. Even high-quality initial teacher education cannot provide teachers with knowledge and skills necessary for teaching during their entire life. Thus, teachers are urged not only to acquire new knowledge and skills but also to develop them continuously.

The European Council held in Lisbon in March 2000 signalized an important moment for the direction of policy and action in the European Union. It concluded that "Europe has indisputably moved into the Knowledge Age". ${ }^{9}$ The way people learn, live and work is changing very quickly. As a result at the Lisbon European Council it was confirmed that "the move towards lifelong learning must accompany a successful transition to a knowledge-based economy and society." ${ }^{10}$ In this respect, the education and professional development of every teacher needs to be seen as a lifelong task. "To equip the teaching body with the skills and competences needed for its new roles, it is necessary to have both quality initial teacher education and a coherent process of continuous professional development to keep teachers up to date with the skills required in a knowledge-based society."11

"Furthermore, as with any modern profession, teachers have the responsibility to extend the boundaries of professional knowledge through a commitment to reflective practice, through research, and through systematic engagement in continuous professional development from the beginning to the end of their careers." 12

There is a crucial characteristic of language which teachers sometimes fail to remember or underestimate; language is dynamic, fluid and changes continually. Thus, the best teachers are those who are also dynamic in the way they develop; always focusing on updating their knowledge of new teaching methodologies and approaches. These teachers are introduced to new methodology and theory to ensure they are kept informed of developments and take an active role in their own professional development.

Good teachers are, after all, students themselves.

\section{Results}

The $21^{\text {st }}$ century offers new challenges to all of us. Students and teachers are faced with a vast range of information which relates to the rapidly changing nature of the educational environment. Teachers strive to prepare students who will

\footnotetext{
${ }^{8}$ Rolheiser, C., and Ross, J. (1998) Student self-evaluation: What research says and what theory shows http://www.cdl.org/resourcelibrary/articles/self_eval.php

${ }^{9}$ European Commission's Memorandum of Lifelong Learning. Brussels 2000, pág. 3

${ }^{10}$ European Commission's Memorandum of Lifelong Learning, Brussels 2000, pág. 3

11 Teachers' Professional Development, Europe in Comparison, Luxembourg: Office for Official Publications of the European Union 2010, pág. 12

12 Teachers' Professional Development, Europe in Comparison, Luxembourg: Office for Official Publications of the European Union 2010, pág. 12
} 
be able to survive in a world which is in constant change. But there is no such teacher education which can provide skills and knowledge necessary for teaching during an entire life. As a result, there comes the need for developing those skills and knowledge constantly, the need to become life-long learners and to grow professionally continuously.

\section{References}

European Commission's Memorandum of Lifelong Learning, Brussels 2000.

Hutchinson, T. (2001) Introduction to Project Work. Oxford University Press. England.

Kelly, M., Grenfell, M., Allan, R., Kriza, C., McEvoy, W. (2004) European Profile for Language Teacher Education-A frame of reference, Final Report

Kemmis, S. and McTaggart, R., (1992) The action research planner Geelong, Victoria, Australia: Deakin University Press

Linn, R., Baker, E., \& Dunbar, S. (1991) Complex performance-based assessment: Expecatiton and validation criteria, Educational Research, 20 (8), 15-21

Merrow, J. (2011) The Influence of teachers: Reflections on teaching and leadership: New York, LM Books

Richards, C., J., (2011) Competences and Performance in Language Teaching, CUP, pp. 3

Rolheiser, C. \& Ross, J.A. (2001). Student self-evaluation: What research says and what practice shows. From http://www.cdl.org/resource-library/articles/self_eval.php

Rolheiser, C., \& Ross, J.A. (2000). Student self-evaluation-What do we know? Orbit, 30(4), 33-36.

Teachers' Professional Development, Europe in International Comparison. Luxembourg: Office for Official Publications of the European Union, 2010. 